УДК 316.621+331.5

DOI: https://doi.org/10.32840/1814-1161/2020-4-21

Назаренко Н.А.

аспірант відділу досліджень людського розвитку Інституту демографрії та соціальних досліджень імені М.В. Птухи

Національної академії наук України

\title{
Nazarenko Nataliia
}

Postgraduate Student, Human Development Research Department Ptoukha Institute for Demography and Social Studies of the National Academy of Sciences of Ukraine

\section{ПОВЕДІНКА МОЛОДІ НА РИНКУ ПРАЦІ: ТИПОЛОГІЗАЦІЯ ЕКОНОМІЧНОЇ ДІЯЛЬНОСТІ}

\section{BEHAVIOR OF YOUNG PEOPLE IN THE LABOR MARKET: TYPOLOGY OF ECONOMIC ACTIVITY}

У статті представлена спроба розкриття поняття «економічна поведінка» з позиції комплексного міждисциплінарного дискурсу із застосуванням системного підходу. Проаналізовано концептуальні основи вивчення соціально-економічної поведінки в сучасних умовах, а також соціолого-економічні підходи до дослідження цього френомена. Розглянуто класичну концепцію раціональності, проаналізовано обмеження ї̈ застосування для пояснення реальної економічної поведінки. Автор доходить висновку, що принцип максимізації, який у класичній економіці розәлядається як центральний, під час аналізу економічної поведінки індивіда діє не завжди. Окреслено структуру та види економічної поведінки. Проаналізовано вплив демографрічних, соціально-економічних, освітньо-професійних та особистісно-мотиваційних чинників на економічну поведінку індивідів. Розроблено типологізацію економічної діяльності.

Ключові слова: економічна поведінка, типологізація економічної поведінки, ринок праці, раціональність, прийняття рішення.

В статье представлена попытка раскрытия понятия «экономическое поведение» с позиции комплексного междисциплинарного дискурса с применением системного подхода. Проанализированы концептуальные основы изучения социально-экономического поведения в современных условиях, а также социолого-экономические подходы к исследованию этого френомена. Рассмотрена классическая концепция рациональности, проанализированы ограничения ее применения для объяснения реального экономического поведения. Автор приходит к выводу, что принцип максимизации, который в классической экономике рассматривается как центральный, при анализе экономического поведения индивида действует не всегда. Обозначены структура и виды экономического поведения. Проанализировано влияние демограффических, социально-экономических, образовательно-профрессиональных и личностно-мотивационных фракторов на экономическое поведение индивидов. Разработана типологизация экономической деятельности.

Ключевые слова: экономическое поведение, типологизация экономического поведения, рынок труда, рациональность, принятие решения.

In modern economics, there are a large number of schools that study the economic behavior of the individual, which is the starting point in the decision-making system. The study of the latest trends in the study of economic behavior of the individual is relevant because it allows us to use new approaches to solve pressing problems in economics. In the conditions of existence of rationalism in the economic science, it is necessary to clearly distinguish which aspects and ideas a certain current explores and which questions it solves, to which scientific ideas the scientific world gravitates and why. Recent research shows that scientists tend to use the ideas of classical economics, because its methodology, ideas and conclusions can solve a number of questions and provide answers to the economic behavior of the individual. The article analyzes rationality as a feature of economic behavior of the individual. Classical economic theory traditionally considers economic behavior as rational, but there is no single interpretation of rationality in economics. Many domestic and foreign publications highlight the basic ideas of modern scientific approaches to economic behavior of the individual. However, these studies do not systematize information on the main types of economic behavior. The purpose of the study is to systematize information on the typology of economic behavior of young people in the labor market. The methodological basis of the article was general scientific and special research methods, including induction, deduction, analysis, synthesis and comparison. The structure and types of economic behavior are outlined. The influence of demographic, socio-economic, educational-professional and personal-motivational factors on the economic behavior of individuals is analyzed. The typology of economic 
activity is developed. Based on the study, the reasons for the application of the ideas of sociology and economics were outlined, and it was also determined that the use of ideas of different approaches is caused by the interdisciplinary of the study. Thus, our typology allows us to state different approaches and criteria for distinguishing different types of economic behavior.

Keywords: economic behavior, typology of economic behavior, labor market, rationality, decision making.

Постановка проблеми. Для сучасного суспільства характерне формування нового соціально-економічного середовища, що характеризується зміною потреб, інтересів, життєвих стандартів. Для розвитку держави особливу увагу варто приділити формуванню інноваційної економічної поведінки однієї з важливих соціальних груп, що бере участь у її становленні та розвитку, а саме молоді, як конкурентоспроможної робочої сили. Побудова сучасної інноваційної економіки неможлива без вивчення та пошуку нових конструктивних моделей поведінки суб'єктів ринку праці. Такі моделі сприятимуть формуванню життєвих орієнтацій, адекватних новим умовам життєдіяльності, а це тією чи іншою мірою впливає на економічну поведінку. На основі теоретичного аналізу можна зробити висновок, що економічна поведінка на ринку праці $\epsilon$ попередньою формою трудової поведінки, пов'язаної з діями суб'єктів на ринку праці під час вибору місця та спеціальності роботи. Пошук ефективних важелів управління соціальними резервами в сучасному житті диктує необхідність типологизації економічної поведінки молоді, яка є основним об'єктом управлінських дій з боку акторів процесу модернізації. Лише встановивши механізми економічної діяльності особистості, можемо зробити усвідомлений і контрольований перехід до економіки інновацій.

Аналіз останніх досліджень і публікацій. Останнім часом у дослідженнях прийняття рішення особлива увага приділяється особистісним властивостям людини, від яких залежить економічний вибір. Основи поведінкової парадигми соціального та економічного аналізу закладені в працях М. Вебера, В. Парето, Л. Мізеса, Дж. Катона, Й. Шумпетера. Серед науковців, що займаються вивченням зайнятості та ринком праці, можемо назвати таких, як Д.Л. Богиня, О.А. Грішнова, Е.М. Лібанова, Л.С. Лісогор, Л.М. Ільїч. На вітчизняному науковому просторі проблеми самореалізації особистості та ії̈ соціально-економічної поведінки досліджували такі вчені, як В.М. Ворона, Є.І. Суїменко, В.І. Тарасенко, В.Е. Пилипенко, Т.О. Петрушина.

У книзі «Теорія ігор і економічної поведінки» економіст Оскар Монгерштейн і математик Джон фон Нейман заклали основи вивчення економічної поведінки [1, с. 57-63]. Автори розглядають людські рішення як раціональні та послідовні, а їх головною метою $є$ максимізація вигоди від цих дій. Вибір робиться в ситуації ймовірності результату, коли потрібно порівняти альтернативи та визначити раціональність кожного варіанта. Подальші дослідження вчених показали, що раціональний вибір - це лише один із можливих варіантів поведінки. На всі подальші дослідження західних науковців відчутний вплив мала програма дослідження Дж. Катона, який займався питаннями психологічних аспектів економічної поведінки [2, с. 308-312]. Погляди науковця побудовані на основі концепції лінгвістичного біхеві- оризму. Його ідея виходить із того, що дія економічних умов на поведінку індивідуума опосередковується суб'єктивними поглядами на економіку.

Варто звернути увагу на ідею Й. Шумпетера про характер поведінки звичайного господарського суб'єкта, який, на думку цього вченого, не змінює ситуацію, що склалася, а переважно пристосовується до неї [3, с. 87]. Фактично йдеться про адаптивний тип соціально-економічної поведінки більшості людей, адже саме більшість має статус звичайного господарського суб'єкта.

Економічна поведінка обумовлена багатьма причинами. У дослідженнях економістів і психологів усе більше спростовується принцип максимізації вигоди від прийнятих рішень. Якщо раніше нераціональна поведінка розглядалась класичною економікою як виняток та аномалія, то тепер психологи та економісти інституціонального напряму стверджують, що раціональне рішення - це лише один із варіантів ухвалення рішення.

Це підтверджується дослідженнями вітчизняних учених. В.М. Ворона та Т.О. Петрушина також вважають, що адекватно осмислити те, що відбувається в економічній сфрері, а потім навчитися керувати ії розвитком у заданому напрямі неможливо без вивчення економічної поведінки людей і тих фракторів, які безпосередньо на ннї впливають [4, с. 45-58].

Фахівцями Інституту соціології НАН України запропоновано типологію, побудовану за способом реагування суб'єктів економічної діяльності на ситуацію напруженості, або за способом виживання та досягнення успіху [5, с. 124-135].

Виділення не вирішених раніше частин загальної проблеми. Погоджуючись загалом із різними дослідженнями економістів та соціологів, маємо зазначити, що більшість досліджень, присвячених вивченню питання економічної поведінки молоді, не дає цілісного системного уявлення щодо структури економічної поведінки особистості. Неповністю висвітлено питання про сутність і чинники впливу на економічну поведінку молоді на новому етапі розвитку суспільства.

Формулювання цілей статті (постановка завдання). У сучасній науковій літературі практично відсутня загальноприйнята універсальна типологія економічної поведінки молоді на ринку праці. Це пояснюється наявністю різноманітних теоретичних макро- та мікропідходів до аналізу економічного життя молоді, його багатовимірністю та складністю. Необхідність відслідковування та систематизації типів економічної поведінки молоді визначила потребу вивчення принципів і чинників формування економічної поведінки молоді на ринку праці. Це дасть змогу у подальших дослідженнях виділити поведінкові стратегії молоді на ринку праці з огляду на отримані результати.

Виклад основного матеріалу дослідження. ICнують різні теоретичні підходи до дослідження ринків 
праці з урахуванням поведінки соціальних суб'єктів. Найбільша увага в тривалих дискусіях економістів і психологів про раціональність економічної діяльності та поведінки була сконцентрована на проблемі ухвалення економічного рішення, що стосується вибору професії або навчального закладу, вибору місця роботи, зміни міста або країни проживання, зміни виду діяльності. Під час вивчення ринку праці науковці проявляли властиву економістам тенденцію перебільшення та абсолютизації когнітивних компонентів, ігнорували існування нематеріальної мотивації, тому в розуміння раціональної поведінки були включені лише економічні мотиви індивіда, що створює ілюзію однорідності суспільства на рівні ментальності. Людина розглядається економістами як егоїстичний індивід, який прагне до власної вигоди, гранично раціональний з точки зору механізму прийняття рішення (постановка мети, розрахунок витрат, вибір засобів досягнення цілей). Індивід володіє повною інформацією про ту ситуацію, в якій він діє, існує в ідеальному середовищі ринкової рівноваги попиту та пропозиції, знає про його основні економічні переваги.

Під час глибшого аналізу ринку праці видно, що особливий вплив на нього мають соціальні фрактори. Економічна поведінка людей не завжди є раціональною та скерованою на максимальний прибуток. Саме соціальні чинники, що притаманні як роботодавцям, так і робітникам, породжують нерівність і конкуренцію на ринку праці [6, с. 113]. У реальному житті немає жорстких кордонів між видами соціально-економічної поведінки, а існують їх поєднання. У певному сенсі протилежні погляди економістів та соціологів компенсують недоліки одні одних, отже, взаємодоповнюються.

У сучасному суспільстві ринок дійсно поширює свої правила поведінки на всі сфери соціуму, тому будемо розглядати його як безліч відносно самостійних світів, які сприяють організації діяльності індивідів за власними правилами й на основі своєї особливої раціональності. Велика кількість людей реалізує свої життєві та економічні інтереси в межах тих традицій і практик поведінки, що є характерними для цього суспільства. В основі реалізації людьми своїх індивідуально-групових інтересів і життєвих перспектив лежить світосприйняття, яке обумовлюється можливостями конкретної соціальної системи в певний історичний період.

Для економічної поведінки характерними є не лише усвідомлення економічних потреб, але й постановка цілей, які визначаються цими потребами, вибір засобів і способів їхнього досягнення. Методи та засоби досягненні цілей в економічній поведінці залежать від особистісних якостей людини та умов її життєдіяльності. Цілі $є$ своєрідними мотиваторами, що спонукають до дії, водночас визначають тип поведінки. Оскільки індивідуальні життєві ресурси не є нескінченними, то людина змушена визначати для себе пріоритетність цілей. Таким чином, економічна поведінка не позбавлена такої характерної ознаки, як оптимальність, тобто вибір найкращого варіанта дії за конкретних умов.

Надмірне спрощення економістами зв'язків між економічними та іншими соціальними змінними ускладнює вивчення характеру економічної поведінки як складного соціально-економічного френомена та не враховує під час аналізу чинники й причини, що обумовлюють економічну поведінку. Індивід здатний чинити всупереч очевидній раціональності або усталеним нормам, переходячи від економічно орієнтованої логіки до логіки соціально орієнтованої дії, і назад.

Як бачимо, економічна поведінка набагато складніше, ніж її подавали в неокласичних економічних теоріях. Варто зазначити, що вона визначається багатьма чинниками, її не вдається чітко описати та однозначно передбачити. Саме це підштовхує до пошуку конструктивно іншої моделі економічної поведінки, що найбільш адекватно відображає багатогранність реальності.

Крім об'єктивних соціальних умов, на специфіку статусної поведінки суб'єкта істотно впливає соціально-психологічний тип особистості суб'єкта. Саме він визначає характер сприйняття соціального та культурного середовища з подальшою рефлексією у відповідних ціннісних установках і судженнях і, як наслідок, виборі конкретного типу поведінки. У своїй поведінці людина орієнтується на прийняті цінності та норми, поводиться відповідно до рольових очікувань, а у виборі засобів досягнення цілей керується не стільки розумом, скільки емоціями та традиціями.

Доцільно детальніше зупинитися на складових частинах реальної економічної поведінки індивіда 3 урахуванням психологічних ланок, які ситуативно зумовлюють його дії на ринку праці (рис. 1). Задля визначення специфічних рис економічної поведінки розглянемо більш широке коло неекономічних змінних, що сприяють кращому розумінню людської поведінки.

1) Інерційність економічної діяльності, коли індивід не реагує на зміни в економічному житті, не пробує покращити свої дії та рішення доти, поки потреба в цьому не стає занадто очевидною.

2) Відмінність мотивацій у робітників та роботодавців.

3) Недостатність інформації для прийняти рішення, за таких умов вибирається один із задовільних варіантів, а найкраще рішення може випасти з поля зору.

4) Прагнення уникнути надмірного ризику, працівники не зацікавлені в максимальних прибутках фірми, оскільки це пов'язано з підвищеною персональною відповідальністю в разі невдачі, тому для збереження свого положення вони вибирають варіанти розвитку, орієнтовані на короткострокові та стабільні прибутки.

5) Прагнення зекономити сили, адже найефективніші рішення дорого коштують, потребують багато затрат, зокрема інтелектуальних, тому індивіди нерідко керуються емоціями, інтуїцією, звичками.

6) Прагнення поділити відповідальність, коли критерієм економічного рішення стає не раціональність, а оптимальність, що означає виваженість, яка обмежена собівартістю продукції.

7) Ситуація, в якій перебувають особи, ухвалюючи рішення; неврахування ситуації може привести до помилкових висновків.

Економічна поведінка на ринку праці - це попередня стадія, яка потім плавно перетікає в трудову поведінку. Поведінка випускника на ринку праці ба- 


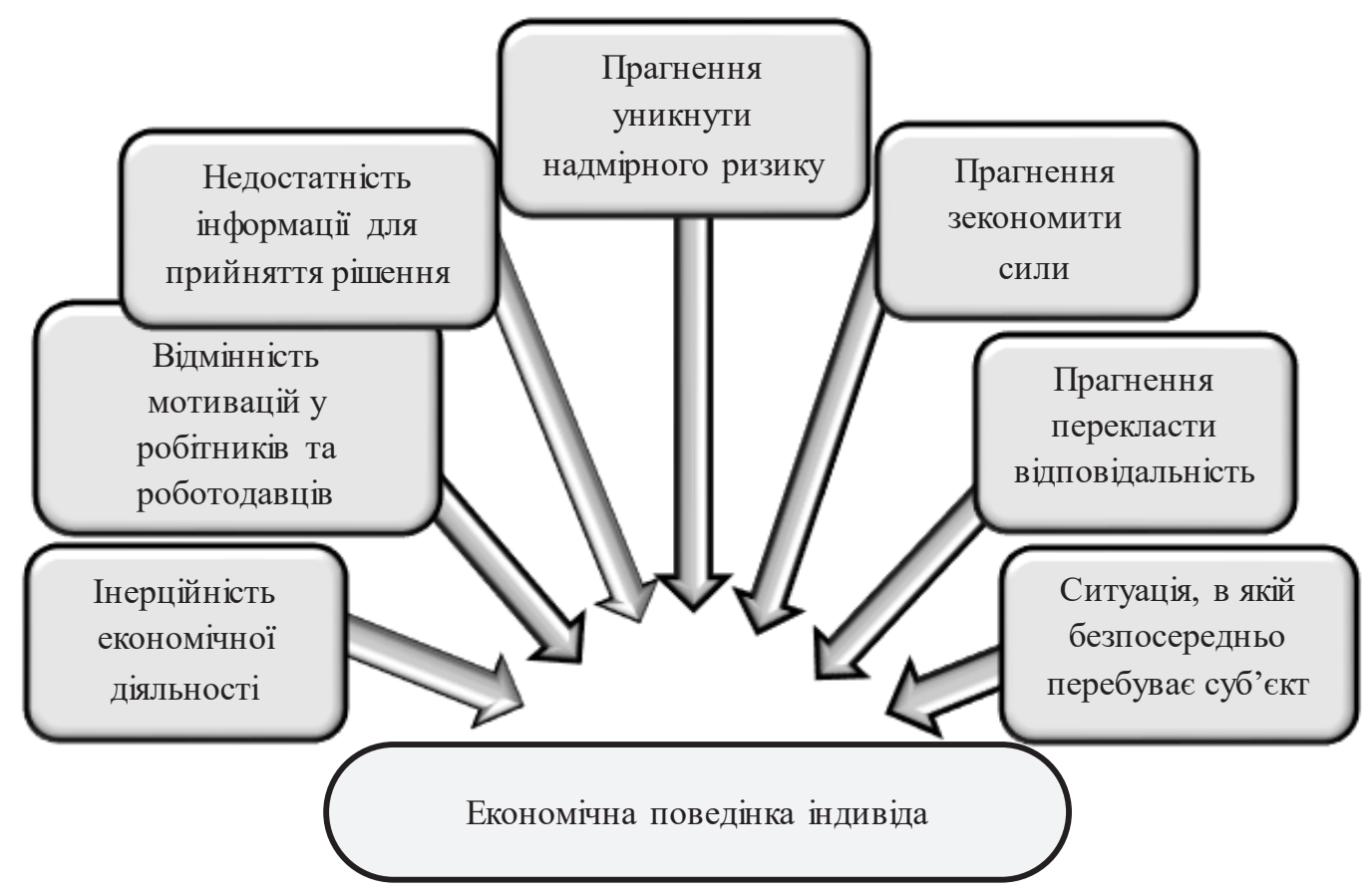

Рис. 1. Складові частини неекономічних змінних реальної економічної поведінки індивіда

зується на його особистих та соціальних установках, які можуть доповнюватися об'єктивним рівнем професійної підготовки. На такі установки можуть впливати різні чинники. Рівень впливу того чи іншого чинника буде завжди різнитися в кожного індивіда. Виявлення подібних закономірностей у поведінці дає змогу підвищити ефективність як системи підготовки фрахівців, так і можливості реального працевлаштування молодих людей. Збіг можливостей і бажань здобувача $є$ свого роду умовою не тільки його соціального задоволення від отриманої роботи, але й раціонального розуміння власного потенціалу. Для того щоби проаналізувати вплив суспільних відносин і розвиток сучасного молодіжного ринку праці, необхідно уявити цей вплив у вигляді класифікації чинників.

У ході дослідження автором було запропоновано розробити класифікацію чинників, які мають вплив на становлення та прояви поведінки молодої людини на ринку праці. Усе різноманіття чинників, які впливають на економічну поведінку людини на ринку праці, можна умовно розподілити на три групи: соціально-економічні, соціально-демографічні та індивідуальні. Ці групи класифрікації обумовлені формами впливу тих чи інших чинників на поведінку індивіда. Для кожного конкретного індивіда більшою чи меншою мірою будуть мати значення конкретні чинники, які зазначені на рис. 2.

Розглянемо запропоновані чинники детально.

Економічні. Тенденції в економічному середовищі країни безпосередньо позначаються на зайнятості молоді [7, с. 45]. Для адекватного оцінювання економічної поведінки молоді на ринку праці необхідно враховувати дію таких чинників:

- структурні перебудови в економіці України, економічна криза, інфляяційні процеси, падіння рівня життя;
- створення чи скорочення робочих місць для молоді, що відображається через показники скорочення зайнятості та зростання безробіття молоді відповідно;

- визначення заробітної плати кожною компанією з огляду на реальний попит і пропозицію на ринку праці;

- підвищення рівня тривалого безробіття молоді;

- наявність прихованих фрорм зайнятості.

Політичні. Вплив зовнішнього середовища $є$ чи не найважливішим із чинників впливу на молодь на ринку праці. Політична ситуація в державі безпосередньо чи опосередковано впливає на діяльність будь-якого суб'єкта господарювання. У країні відбувається складний період трансформацій: зміни в чинному законодавстві, державній політиці, виборчі процеси в країні, посилення державного контролю за діяльністю суб'єктів господарювання, жорсткі штрафні санкції [8, с. 83].

Технологічні. Науково-технічний прогрес, поява новітніх інформаційних технологій та систем сприяють збільшенню кількості новітніх технологічних галузей, відповідно, збільшенню робочих місць [7, с. 47]. 3 іншого боку, впровадження нових технологій покращує продуктивність праці, що сприяє скороченню первинних робочих місць, а також веде до підвищення рівня безробіття.

Корпоративна соціальна відповідальність бізнесу. Фінансові показники компанії $€$ об'єктивною інформацією про ії діяльність та можуть показати ринкову вартість підприємства, ліквідність тощо. Корпоративна соціальна відповідальність - це добровільний внесок бізнеса в розвиток суспільства в соціальній, економічній та екологічній сфрерах, пов'язаних безпосередньо з основною діяльністю компанії, а також виходить за рамки визначеного законом мінімуму. 


\section{Чинники}

\begin{tabular}{|c|c|c|}
\hline Соціально-економічні & Соціально-демографічні & Індивідуальні \\
\hline $\begin{array}{l}\text { Економічні } \\
\text { (економічна ситуація в } \\
\text { державі, рівень інфляції, } \\
\text { заробітна плата, } \\
\text { податкова система) }\end{array}$ & $\begin{array}{l}\text { Демографічні } \\
\text { (чисельніеть населення, } \\
\text { вік і стать, склад сім'ї, } \\
\text { тривалість життя, } \\
\text { динаміка шлюбів) }\end{array}$ & $\begin{array}{l}\text { Медико-біологічні } \\
\text { (можливості організму, } \\
\text { біологічні ритми, фактори } \\
\text { пеихічного розвитку) }\end{array}$ \\
\hline $\begin{array}{l}\text { Політичні } \\
\text { (політична ситуація в } \\
\text { державі, зміни в державній } \\
\text { політиці, вплив } \\
\text { міжнародного } \\
\text { законодаветва) }\end{array}$ & $\begin{array}{l}\text { Юридичні } \\
\text { (рівень правової } \\
\text { культури суспі.льства, } \\
\text { офіційні відносини, } \\
\text { сиетема страхування) }\end{array}$ & $\begin{array}{l}\text { Гендерні } \\
\text { (чоловіче і жіноче } \\
\text { сприйняття роботи) }\end{array}$ \\
\hline $\begin{array}{l}\text { Технологічні } \\
\text { (впровадження інновацій, } \\
\text { високий розвиток науки, } \\
\text { вільний доступ до } \\
\text { технологій) }\end{array}$ & $\begin{array}{l}\text { Соціальні } \\
\text { (рівень соціальної } \\
\text { стратифікації, спадкові } \\
\text { стереотипи, соціальні та } \\
\text { моральні норми) }\end{array}$ & $\begin{array}{l}\text { Пеихологічні } \\
\text { (пеихічні особливості } \\
\text { людини) }\end{array}$ \\
\hline $\begin{array}{l}\text { Ћорпоративна сопіальна } \\
\text { відповідальність бізнесу } \\
\text { (фінансові показники } \\
\text { підприємства, умови } \\
\text { праці, соціальна } \\
\text { відповідальність бізнесу) }\end{array}$ & $\begin{array}{l}\frac{\text { Чинники державного }}{\text { регуловання питань }} \\
\text { аайнятості та ринку праці } \\
\text { (державна політика } \\
\text { зайнятості, наявність } \\
\text { профепілок) }\end{array}$ & $\begin{array}{l}\text { Екологічні } \\
\text { (споживча екологічна } \\
\text { поведінка, бажання } \\
\text { працювати в кращих } \\
\text { екологічних умовах) }\end{array}$ \\
\hline
\end{tabular}

Рис. 2. Чинники, що впливають на економічну поведінку молоді на ринку праці

Джерело: складено автором

Екологічна відповідальність компанії перед суспільством. Швейцарський економіст Х.К. Бінсвангер, досліджуючи межі соціальної держави, говорив про посилення взаємозв'язку праці, робочих місць і можливого руйнування навколишнього середовища [9, с. 37], що нині знайшло відображення в концепції «зеленої» зайнятості. Однак багато компаній слабо позиціонуються як екологічно відповідальні, що обумовлено такими чинниками, як низька культура ведення бізнесу з урахуванням вимог охорони навколишнього середовища, недостатнє фрінансування природоохоронної діяльності, виробництво недостатньо екологічної та енергетично-ефрективної продукції.

Соціально-демографрічні чинники. Чисельність населення, динаміка народжуваності («демографічні ями»), відтворення населення визначають попит і пропозицію на ринку праці. «Демографрічні ями» (спад народжуваності у 1992 році) впливають на специфіку організації професійної підготовки (попит зменшується) і робочих місць (менший обсяг випускників порівняно із загальними показниками зайнятих). Падіння рівня життя безпосередньо відображається на народжуваності населення.

Гендерні відмінності чоловіків і жінок впливають на специфіку робочої діяльності. Моральні норми сучасного суспільства визнає існування «чоловічих» і «жіночих» професій. Гендерна дискримінація унеможливлює працевлаштування жінок на більш престижні високооплачувані посади. Дискримінація за віком $є$ поширеним явищем на ринку праці України, адже невелика кількість роботодавців готова працевлаштувати молодь без досвіду роботи.

Сімейний стан $€$ визначальним чинником під час прийняття на роботу, яка пов'язана з частими відрядженнями та ненормованим робочим днем, роботодавці неохоче беруть на роботу вагітних, жінок із малолітніми дітьми та дітьми-інвалідами через можливу відсутність на робочому місці. Повнота сім'ї потужно впливає на психологічний комфорт особистості. Кількість дітей у сім'ї - це показник відтворення населення та економічної стабільності суспільства.

Тривалість життя визначає максимальний трудовий вік населення. За статистичними даними, для України середня тривалість життя жінок становить 77 роки, чоловіків - 67 років. Пенсійний вік, встановлений для жінок та чоловіків, становить 60 років [10].

Юридичні чинники. Правова культура відображає не тільки індивідуальне та особисте ставлення індивіда чи групи до правових норм, але й шанування правових традицій суспільства. Феномен правової 
культури прив'язаний до конкретного соціально-історичного розвитку окремої країни. Сучасна правова культура має бути заснована на принципах свободи, рівності та справедливості. Для української дійсності характерні досить зневажливе ставлення до правових норм і цінностей, прихована зайнятість. Особливо це стосується молодого покоління, часто трудові відносини між молодими людьми й роботодавцями відбуваються без юридично оформленого договору.

Соціальні чинники. Фізичне оточення - це соціальне середовище, яке оточує людину та має вплив на ней. Ступінь включення індивіда в культурно-соціальне середовище суспільства визначається рівнем соціалізації. Емоційна прихильність до певного культурного середовища буде спрямовувати людину до свого близького оточення та визначати процес входження індивіда в інші соціальні групи. Так, наша сім'я й близькі родичі впливають на вибір майбутньої профресії та місця роботи. Фізичне оточення включає певні спадкові стереотипи, які можуть відображатися на професійній соціалізації. Так, наприклад, у сім'ї медиків отримання медичної освіти - це сімейна цінність і стереотип, який передається від батьків до дітей.

Соціальні та моральні норми суспільства позначають стереотипи, що склалися, які приймають та розділяють як великі, так і малі соціальні групи. Відхилення від таких прийнятих норм сприймається суспільством як девіантна поведінка. До таких норм можна віднести також релігійні звичаї, які впливають на наше повсякденне життя. Морально-етичні цінності, менталітет, етнічні чинники залежать від впливу низки історико-культурних умов та обставин держави.

Чинники державного регулювання питань зайнятості та ринку праці. Державне регулювання ринку праці спрямоване скоріше на стримання безробіття, ніж на створення умов для продуктивної зайнятості. Соціальне забезпечення з боку держави (державна політика підтримки зайнятості) має спрямовуватись на створення рівних можливостей для людей з обмеженими фізичними можливостями, забезпечення професійного навчання, працевлаштування та отримання гідної заробітної плати. Наявність громадянського суспільства, профрспілок - це системна цілеспрямована взаємодія органів влади, органів місцевого самоврядування, медичних і навчальних закладів, фондів соціального страхування, громадських організацій, волонтерів тощо.

Медико-біологічні фрактори. До цих фракторів можна віднести дотримання здорового способу життя (режим дня, здорове та збалансоване харчування, активний спосіб життя, фрізичні навантаження); обмежені фрізичні можливості людини; стан психіки людини, що визначає ії ставлення до процесів, що відбуваються в житті; комплекс медичних показників, які визначають працездатність людини.

Гендерні чинники. Основна особливість вивчення гендерних підходів до розуміння та стратегії пошуку роботи полягає в тому, що для жінки існують дві сорери праці, а саме оплачувана робота та домашня діяльність. Виходячи на ринок праці, жінка прагне знайти таке місце роботи, яке буде відповідати її вимогам до поєднання цих двох галузей. Так само чо- ловіки мають проблеми з працевлаштуванням, адже спостерігається зростання безробіття чоловіків, причому в молодому та працездатному віці.

Психологічні чинники. Можна виділити такі психологічні фрактори, як прагнення, спрямованість особистості та емоційний інтелект. Особливо сильно виділяється емоційний інтелект людини, який визначається як здатність розуміти свої почуття та емоції і керувати ними, а також розуміти почуття інших людей. У зв'язку з цим прийняття рішення про вибір майбутнього фаху та ВНЗ для його отримання - це емоційне, довгострокове рішення, можливо, такий вибір більшість робить лише раз у житті. Таке рішення приймається в умовах невизначеності, що ще більше ставить під сумнів раціональність прийнятого рішення. Ситуація невизначеності додає ірраціональне в стандартну економічну модель прийняття рішень, абітурієнт не здатний прорахувати всі систематичні помилки. Судити про якість отриманої освіти неможливо, поки сам не закінчиш ВН3, і розуміння корисності освіти в кожного своє.

Екологічні фрактори. Споживча поведінка відзначається бажанням купувати екологічно чисті продукти, проживати в екологічно чистих районах. Бажання витратити більше коштів на екотовари та послуги ще раз доводить парадокси впливів соціальних установок на економічну поведінку людини. За результатами наукових досліджень, екологічна орієнтація споживчої поведінки сучасної молоді досить низька. Переважно це обумовлено низькими матеріальними доходами молодого покоління, адже багато молодих людей не мають постійного та стабільного місця роботи. Інша причина полягає в тому, що більшість випускників проживає разом зі своїми батьками та не піклується про покупку продуктів. Визначальним $€$ бажання працювати в комфортних умовах. Перш за все це дотримання компанією норм охорони праці. Комфортні робочі умови передбачають можливість перекусити в робочий час, дотримання температурного режиму, зручне робоче місце, зручне розташування офрісу компанії, чистоту та щоденне прибирання в офрici.

Важливим етапом дослідження економічної поведінки молоді $€$ її типологізація, тобто виявлення ієрархічно розгорнених типів і видів цієї поведінки на тих чи інших підставах, надання їм логічної впорядкованості. Це викликано перш за все неопрацьованістю відповідного методологічного інструментарію, відсутністю загальноприйнятих принципів такої типологізації.

Типологізація дає змогу розкрити різноманіття типів і видів цієї поведінки, виявити в них спільне та особливе, глибше зрозуміти сутність і можливі форми проявів окремих складових частин соціально-економічної поведінки, вловити тенденції та закономірності ії̈ еволюції і, як наслідок, досягти такого комплексного, системного розуміння цього явища, яке необхідне для управління ним.

Типологізація має здійснюватися з урахуванням теоретичного та емпіричного рівнів науки. На відміну від емпіричної типології, де головним інструментом її побудови є багаторазовий перебір емпірично виявлених реальних характеристик, теоретична 
типологія заснована на логічному аналізі ідеальної теоретичної моделі за теоретично обґрунтованими критеріями [11, с. 7].

Багатовимірність соціально-економічного простору є підставою для типологізації соціально-економічної поведінки за предметними ознаками, а плинність, мінливість соціального середовища дають змогу говорити про різний ступінь сорормованості тих чи інших типів і видів соціально-економічної поведінки за процесуально-тимчасовими ознаками.

До структурних елементів, що формують виникнення економічної поведінки належать такі найважливіші умови, як мотивація, вид зайнятості, ступінь реалізації отриманої освіти, ступінь реалізації людського капіталу, спрямованість пошуку робочого місця. Мотивація багато в чому визначає форму раціональності економічної поведінки суб'єкта та відповідає на питання, для чого індивіду робота. Отже, мотивація буває економічною (отримання матеріальної винагороди), соціально-психологічною (можливість власної самореалізації), соціально-економічною (поєднання економічного добробуту з можливістю самореалізації).

Характерна для сучасного українського ринку праці структура зайнятості формує особливості ринкових відносин, а саме визначає, якою формою правового регулювання будуть оформлені трудові взаємини: легальне оформлення трудових відносин із отриманням повної заробітної плати відповідно до трудового законодавства України, легальне оформлення трудових відносин із отриманням неповної заробітної плати («сіра зарплата») відповідно до трудового законодавства України або відсутність легального оформлення трудових відносин.

Ще однією характеристикою економічної поведінки $є$ сприйняття суспільством та індивідом трудової діяльності, тобто як суспільство ставиться до процесу пошуку роботи та як сам індивід переймається цим процесом. Ставлення соціуму, яке оточує, може підсилювати або послаблювати цілеспрямованість та активність людини (соціально схвалювана поведінка, соціально несхвалювана поведінка й нейтральне ставлення) [12, с. 168-172]. Особисте ставлення передбачає ефективність задоволення потреб у благах і послугах та інтересів інших людей, колективів чи спільнот, що надає соціального змісту трудовій діяльності людини (соціально значуща, егоїстично раціональна чи нейтральна поведінка).

Норми та правила, що діють у суспільстві, здійснюють істотний вплив на поведінку економічних суб'єктів, створюють певні альтернативи дій, фрормують відповідний стиль поведінки. Підсумковою характеристикою економічної поведінки є ступінь прийняття соціальних і моральних норм, як саме індивід дотримується схвалюваних суспільством соціальних та моральних норм (повне чи часткове дотримання норм та правил, повне заперечення чи нейтральне ставлення).

Класифікація типів економічної поведінки на ринку праці здійснюється за такими ознаками:

- характер мотивації (Навіщо індивід шукає роботу?): економічна - отримання матеріальної винагороди; соціально-психологічна - можливість власної самореалізації; соціально-економічна - поєднання економічного добробуту з можливістю самореалізації;

- характер зайнятості (На яку зайнятість розраховує індивід?): постійна; ненормована; гнучка; позмінна;

- ступінь мобільності (Як індивід просувається кар'єрними сходами?): горизонтальна; вертикальна; первинна;

- ступінь раціональності (Наскільки раціонально індивід приймає рішення?): цілераціональна; ціннісно-раціональна; афективна; традиційна;

- ступінь реалізації отриманої освіти (Як індивід буде використовувати отриману освіту для робочої діяльності?): робота за спеціальністю; робота за суміжною спеціальністю; робота без використання освіти; робота з профеесійної перепідготовки;

- ступінь реалізації людського капіталу (Як індивід збирається використовувати особисті якості?): високий; середній; низький; відсутність;

- ступінь трудової мобільності (Чи готовий працівник до зміни підприємства, галузі роботи, регіону, населеного пункту?): високий; середній; низький; відсутність;

- характер пошуку робочого місця (За допомогою яких каналів здійснюється пошук робочого місця?): мережевий - за кошти професійних зв'язків; пасивний - індивід не перебуває в активному пошуку, роботодавці не показують активну зацікавленість у цьому співробітнику; традиційний - використання служб зайнятості, кадрових агентств, сайтів із працевлаштування; інноваційний - соціальні мережі, форуми, за допомогою «сарафанного радіо»;

- пріоритет соціальних факторів (Чи вважає індивід пріоритетом соціальні фактори?): соціально відповідальний; соціально орієнтований; антисоціальний;

- ступінь прийняття професійно-трудових норм (Як індивід ставиться до професійного та посадового етикету?): повне прийняття; часткове прийняття; повне заперечення; нейтральне;

- форма правового регулювання (Якою фрормою правового регулювання будуть оформлені трудові взаємини?): легальне оформлення трудових відносин із отриманням повної заробітної плати відповідно до трудового законодавства України; легальне оформлення трудових відносин із отриманням неповної заробітної плати («сіра зарплата») відповідно до трудового законодавства України; відсутність легального оформлення трудових відносин;

- характер сприйняття суспільством трудової діяльності (Як суспільство ставиться до процесу пошуку роботи?): соціально схвалювана поведінка; соціально несхвалювана поведінка; нейтральне ставлення;

- характер сприйняття соціально-економічної ситуації в державі (Як індивід ставиться до свого положення в соціально-економічному просторі - активна/пасивна форма?): адаптивний, скерований на збереження усталених норм, стереотипів і принципів поведінки; протестний, що виникає як наслідок неузгодженості інтересів суб'єктів ринку праці з алгоритмом їхньої діяльності; творчий, який охоплює систему дій та вчинків, пов'язаних зі створенням власної справи, ризиком, новаторством; 
- характер дотримання норм та законів (Як індивід визнає встановлені норми та закони в державі?): легітимний; нелегітимний; легальний; нелегальний;

- характер сприйняття процесу пошуку роботи (Як індивід ставиться до процесу пошуку роботи?): соціально значущий; егоїстично-раціональний; нейтральний;

- ступінь ставлення до «креативності» та «сформованого порядку речей» (Як індивід ставиться до креативу та інновацій?): інноваційне; традиційне; нейтральне;

- ступінь прийняття соціальних і моральних норм (Як індивід дотримується прийнятих і схвалюваних суспільством соціальних та моральних норм?): повне прийняття; часткове прийняття; повне заперечення; нейтральне;

На підставі аналізу умов формування типів економічної поведінки індивідів на ринку праці можна стверджувати, що у реальних ситуаціях результати економічної поведінки можуть мати деякі відхилення від чіткого дотримання вимог економічного принципу, оскільки під час втілення в конкретних рішеннях і діях не завжди відповідають правилам раціонального вибору.

Висновки. Таким чином, здійснена нами типологізація дає змогу констатувати різні методи та критерії виокремлення різних типів економічної поведінки. 3 одного боку, в економічній науці немає усталеної та розгорнутої типології економічної поведінки, а з іншого боку, існує досить велика кількість типологій цієї поведінки, які не тільки не заперечують і не виключають одна одну, а навіть відображають взаємодоповнюючі аспекти процесу пізнання, бо свідчать про творчий пошук типологічних характеристик складного соціально-економічного феномена. Це ускладнює дослідницьку проблему конструювання універсальної типології економічної поведінки, водночас сприяє комплексному, системному розумінню цього феномена та дає змогу трактувати економічну поведінку як доцільну активність людини, що відповідає найбільш значущим для неї інтересам і потребам, отже, визначається скоординованою системою дій людини, які скеровані на задоволення широкого спектру потреб і детерміновані інституційними параметрами. Вивчення економічної поведінки молоді на ринку праці підтвердило, з одного боку, актуальність і досконале теоретичне пророблення цієї проблеми, а з іншого боку, відсутність практичного використання результатів теоретичних досліджень.

\section{Бібліографічний список:}

1. фон Нейман Дж., Моргенштерн О. Теория игр и экономическое поведение. Москва, 1970. 708 с.

2. Katona, G. Rational behavior and economic behavior. Psychological Review. 1953. № 60(5). P. 307-318.

3. Шумпетер Й.А. Теорія економічного розвитку: дослідження прибутків, капіталу, кредиту, відсотка та економічного циклу. Київ : Видавничий дім «Києво-Могилянська академія», 2011. 242 с.

4. Социальный потенциал инновационного развития экономики: украинские реалии / под ред. В.М. Вороны, Т.О. Петрушиной. Киев : Институт социологии НАН Украины, 2014. 328 с.

5. Ворона В.М., Пилипенко В.Є., Тарасенко В.І. та ін. Економічна соціологія : навчальний посібник. Київ : Інститут соціології НАН України, 1997. 273 с.
6. Суименко Е.И, Ворона В.М., Тарасенко В.И. Промышленное предприятие и его люди: проблемы социально-экономического поведения. Киев, 2001. $351 \mathrm{c}$.

7. Лісогор Л.С. Якість трудового життя: чинники впливу та напрями покращення. Демографрія та соціальна економіка. 2012. № 2(18). С. 43-52.

8. Лісогор Л.С. Чинники впливу на якість трудового життя в умовах економічної кризи. Демографрія та соціальна економіка. 2011. № 1(15). С. 79-85.

9. Binswanger H.K. U.a. Arbeit ohne Umweltzerstoerung. Strategien einer Wirtschaftspolitik. Frankfurt am Main : S. Fischer Verlag, 1983. $367 \mathrm{~s}$.

10. Про загальнообов'язкове державне пенсійне страхування : Закон України від 9 липня 2003 року № 1058-IV / Верховна Рада України. Відомості Верховної Ради України. 2003. № 49-51. Ст. 376.

11. Пилипенко В.Е. Социальная регуляция трудового поведения. Киев, 1993. 178 с.

12. Суїменко $€$.І. Економічна поведінка: експлікація поняття і типологічна характеристика. Соціологія: теорія, методи, маркетине. 2002. № 4. С. 168-188.

\section{References:}

1. fon Neyman Dzh., Morgenshtern O. (1970) Teoriya igr $i$ ekonomicheskoe povedenie [Game theory and economic behavior]. Moscow. (in Russian)

2. Katona, G. (1953). Rational behavior and economic behavior. Psychological Review, vol. 60, no. 5, pp. 307-318.

3. Shumpeter Y.A. (2011) Teoriia ekonomichnoho rozvytku: Doslidzhennia prybutkiv, kapitalu, kredytu, vidsotka ta ekonomichnoho tsyklu [Theory of Economic Development: A Study of Profit, Capital, Credit, Interest, and the Economic Cycle]. Kyiv: Kyievo-Mohylianska akademiia. (in Ukrainian)

4. Vorona V.M., Petrushina T.O. (ed.) (2014) Sotsial'nyy potentsial innovatsionnogo razvitiya ekonomiki: ukrainskie realii [Social potential of innovative economic development: Ukrainian realities]. Kiev: Institute sociology NAS Ukraine. (in Russian)

5. Vorona V.M., Pylypenko V.Ye., Tarasenko V.I. and other (1997) Ekonomichna sotsiolohiia: Navchalnyi posibnyk [Economic Sociology: A Textbook]. Kyiv: Institute sociology NAS Ukraine. (in Ukrainian)

6. Suimenko Ye.I., Vorona V.M., Tarasenko V.I. (2001) Promushlennoe predpryiatye y eho liudy: problemu sotsyalno-ekonomycheskoho povedenyia [Industrial enterprise and its people: problems of socio-economic behavior]. Kyiv. (in Russian)

7. Lisohor L.S. (2012) Yakist trudovoho zhyttia: chynnyky vplyvu ta napriamy pokrashchennia [The quality of work life: officials injected that]. Demohrafiia ta sotsialna ekonomika, vol. 18, no. 2, pp. 43-52.

8. Lisohor L.S. (2011) Chynnyky vplyvu na yakist trudovoho zhyttia $v$ umovakh ekonomichnoi kryzy [Factors influencing the quality of working life in the economic crisis]. Demohrafiia ta sotsialna ekonomika, vol. 15, no. 1, pp. 79-85.

9. Binswanger H.K. (1983) Arbeit ohne Umweltzerstoerung Strategien einer Wirtschaftspolitik [Work without environmental destruction Strategies of economic policy]. Frankfurt am Main: S. Fischer Verlag. (in German)

10. Information of the Verkhovna Rada of Ukraine (2003) Pro zahalnooboviazkove derzhavne pensiine strakhuvannia: Zakon Ukrainy vid 9 lypnia 2003 r. № 1058-IV [On Compulsory State Pension Insurance: Law of Ukraine of July 9, 2003 № 1058-IV]. Kyiv. (in Ukrainian)

11. Pilipenko V.E. (1993) Sotsial'naya regulyatsiya trudovogo povedeniya [Social regulation of labor behavior]. Kyiv.

12. Suimenko Ye.I. (2002) Ekonomichna povedinka: eksplikatsiia poniattia i typolohichna kharakterystyka [Economic behavior: explication of the concept and typological characteristics]. Sotsiolohiia: teoriia, metody, marktynh, no. 4. pp. 168-188. 